\title{
BCOR/CCNB3 Fusion Protein
}

National Cancer Institute

\section{Source}

National Cancer Institute. BCOR/CCNB3 Fusion Protein. NCI Thesaurus. Code C139677.

A fusion protein encoded by the BCOR/CCNB3 fusion gene. This protein is comprised of the BCL6 co-repressor protein, which includes its three ankyrin domains, fused to the Cterminal portion of the G2/mitotic-specific cyclin-B3, which includes its two cyclin domains. 